\title{
THE CONSTRUCTION SECTOR IN TWENTY EUROPEAN COUNTRIES DURING THE RECESSION 2008-2009 - COUNTRY RANKING BY MULTIMOORA
}

\author{
Willem Karel M. BRAUERS $1 \bowtie$, Simona KILDIENE் ${ }^{2}$, \\ Edmundas Kazimieras ZAVADSKAS ${ }^{3}$ and Artūras KAKLAUSKAS ${ }^{4}$ \\ ${ }^{1}$ Faculty of Applied Economics, University of Antwerp, Prinsstraat 13, B2000, Antwerpen, \\ Belgium \\ E-mail: willem.brauers@ua.ac.be \\ ${ }^{2}$ Department of Construction Technology and Management, Vilnius Gediminas Technical \\ University, Sauletekio al. 11, LT-10223 Vilnius, Lithuania \\ E-mail: simona.kildiene@vgtu.lt \\ ${ }^{3}$ Department of Construction Technology and Management, Vilnius Gediminas Technical \\ University, Sauletekio al. 11, LT-10223 Vilnius, Lithuania \\ E-mail: edmundas.zavadskas@vgtu.lt \\ ${ }^{4}$ Department of Construction Economics and Property Management, Vilnius Gediminas \\ Technical University, Sauletekio al. 11, LT-10223 Vilnius, Lithuania \\ E-mail: arturas.kaklauskas@vgtu.lt
}

Received 28 December 2011; accepted 29 June 2012

\begin{abstract}
The recession 2008-2009 which influenced the World economy has set new challenges for the development of the European construction sector. In the years 2008-2009 a great number of countries faced serious production and employment breakdowns. The purpose of this paper is to analyze the construction sector from a macroeconomic point of view by comparing construction market variations appeared during the crisis in twenty European countries. Therefore statistical indicators of the construction sector were used and a multiobjective evaluation method under the name of MULTIMOORA was employed. However these traditional indicators of the construction sector deliver an incomplete definition of real situations within the sector as during the recession plenty of constructed buildings remained unsold. Therefore the authors of this article propose a rather complex comparison of construction indicators for different European countries. The case study provides the analysis and calculations performed with the help of the MULTIMOORA method. This method enables the evaluation of European countries in accordance with the investigated objectives and ranges them into different groups according to the objectives set for the construction sector.
\end{abstract}

KEYWORDS: European Union; Construction sector; Recession; MULTIMOORA

REFERENCE to this paper should be made as follows: Brauers, W. K. M., Kildienè, S., Zavadskas, E. K. and Kaklauskas, A. (2013) The construction sector in twenty European countries during the recession 2008-2009 - country ranking by multimoora, International Journal of Strategic Property Management, 17(1), pp. 58-78.

JEL: C02, C13, C44, C61, E23, F02, P52

Copyright (C 2013 Vilnius Gediminas Technical University (VGTU) Press Technika http://www.tandfonline.com/TSPM 


\section{INTRODUCTION}

It is the intention of the authors to study from a macroeconomic point of view the Construction Sector for a selection of European countries during the Recession 2008-2009. The economic recession, which is called the "Great Recession", compared to the Great Depression of 1929, lasted approximately from 2008 until 2009 (Auerbach et al., 2010; Hall, 2010; Mishkin, 2011).

Each recession has its own specific causes, but all of them are usually preceded by a period of irrational exuberance. This is also known as a business cycle. The present crisis was caused by a combination of asset price bubbles, mainly in the real estate sector, and of a credit bubble. Although the crisis went global, it is still hitting different countries in quite different ways. It has become a popular pastime to rank countries by the fall they experienced in GDP and then pass judgment accordingly on their "economic model" (Gros and Alcidi, 2009).

The construction sector is regarded as a significant factor influencing the economic policies of the countries. Indicators for the construction sector express general level of country economy as well. Position within the construction sector also depends on general economic processes that are conditioned by fluctuations of national and international economic systems.

In fact, the construction sector in the European countries is a main provider of employment and contributes for a major part to the Gross capital of the European countries. In European Union countries gross investment in the building and construction sector accounted for approximately $66 \%$ of total investment in the economy and $12.8 \%$ of GDP in 2009 . New residential construction alone accounted for $3.4 \%$ of GDP compared with $7.3 \%$ in 2008 and approximately $11.2 \%$ in 2007 (Department of the Environment ..., 2010).

In this article the MULTIMOORA multi-objective analysis methods (Brauers and Zavadskas, 2010) will be applied in order to analyze the construction sector of the European countries taking into account the macro economic situation in the determined countries in the 2007-2009 period. The research is performed employing the statistical and analytical indicators of European Commission (2010a) and the databases of the Department of the Environment ... (2010).

The European states construction sector study developed by the authors includes the following stages.

Stage I. A disquisitional description is written on the construction sector of some European states which includes a system of objectives (total construction, total employment; civil engineering; rehabilitation and maintenance; construction cost index number; index number of building permits for new residential buildings and index numbers of building permits for new offices.

Stage II. Overview of the development of the MOORA and MULTIMOORA methods with their calculations. Final ranking for each year was obtained by the Dominance Theory.

Stage III. A comparison for some European states construction sectors are performed which include:

- An identification of global development trends (general regularities) in the construction sector.

- An identification of construction sector differences between the European countries.

Stage IV. A multiple objective analysis is performed on the components of the construction sector.

\section{DEVELOPMENT OF A DECISION MAKING MATRIX FOR THE CONSTRUCTION SECTOR OF TWENTY EUROPEAN COUNTRIES}

A quantitative evaluation of the construction sector in European countries is based on indicators describing situations of the construction 
sector in each particular country and using multi-objective evaluation methods. A system of indicators has to consist of indicators identifying most important dimensions of sectoral progress (Table 1).

Table 1 introduces statistical indicators for the construction sector of twenty European countries, describing the decrease/increase of the particular objectives within the year (comparison of 2008-2009 data compared with the previous year).

In this case, seven substantial objectives were selected:

- Total employment in construction sector. Rate represents employed persons in construction sector. It is a ratio of the total employed population over the total number of people aged 15-65;

- Total construction. The production index number for construction which measures changes in the price adjusted output of construction (the indicators in this sector cover economic activities listed in section F of NACE (National Classification of Economic Activities, 2008);

- Civil engineering. The production index number for civil engineering which measures changes in real terms on previous year the price adjusted output of civil engineering constructions (consist of: roads, streets, and highways; railroads; harbors; airports; canals and waterways; pipelines for gas, water and sewer systems; telephone and telegraphs systems; electricity transmission infrastructure; oil wells, gas wells, mine shafts, dams, dikes etc.);

- Rehabilitation and maintenance. Investment in production of construction rehabilitation and maintenance;

- Index number of building permits new (residential/office) buildings - it is an authorization to start work on a building project, and as such is the final stage of authorization prior to the start of the work.

- Construction cost index number shows the development of costs incurred by the contractor to carry out the construction process. Costs that constitute components of the construction costs include material costs, labor cost, plant and equipment costs, transport and energy costs.

However, the construction indicators can not reflect the real situation in the construction sector. With a few exceptions (for example, employment in construction sector), construction indicators (total construction, civil engineering, rehabilitation and maintenance production) count construction production that pass through markets. Construction production that is not bought or sold does not generally get counted. During the crisis period plenty of constructed buildings remain unsold. It can be evaluated indirectly taking into account particular deviations. During the construction bubble constructors have been working overtime. For example, in construction works, executed in Lithuania, constructors have been working 65 hours per week.

Due to insufficient data for some of the 27 European Union Member States 1) Luxemburg 2) Latvia 3) Italy 4) Greece 5) Hungary 6) Slovakia 7) Poland 8) Malta were not considered. On the other side Norway was included, a non EU Member State.

In Table 1 each figure has the previous year as a basis. i.e. for 2008 it is 2007 and for 2009 it is 2008 .

The years 2007-2009 were critical for most European countries. No European country has been exempt from the economic crisis, and here the construction sector is also included. Gross Domestic Product (GDP) has decreased in most of the European countries. GDP and construction sector fluctuations are interdependent. There exist a great number of studies which have analyzed the relation between construction growth data (infrastructure, building investment) and gross domestic product (GDP) (Ozkan et al., 2011; Duca et al., 2010; Wilhelmsson and Wigren, 2011; Wigren and Wilhelmsson, 2007; Ruddock and Lopes, 2006; Giang and Pheng, 2011). 


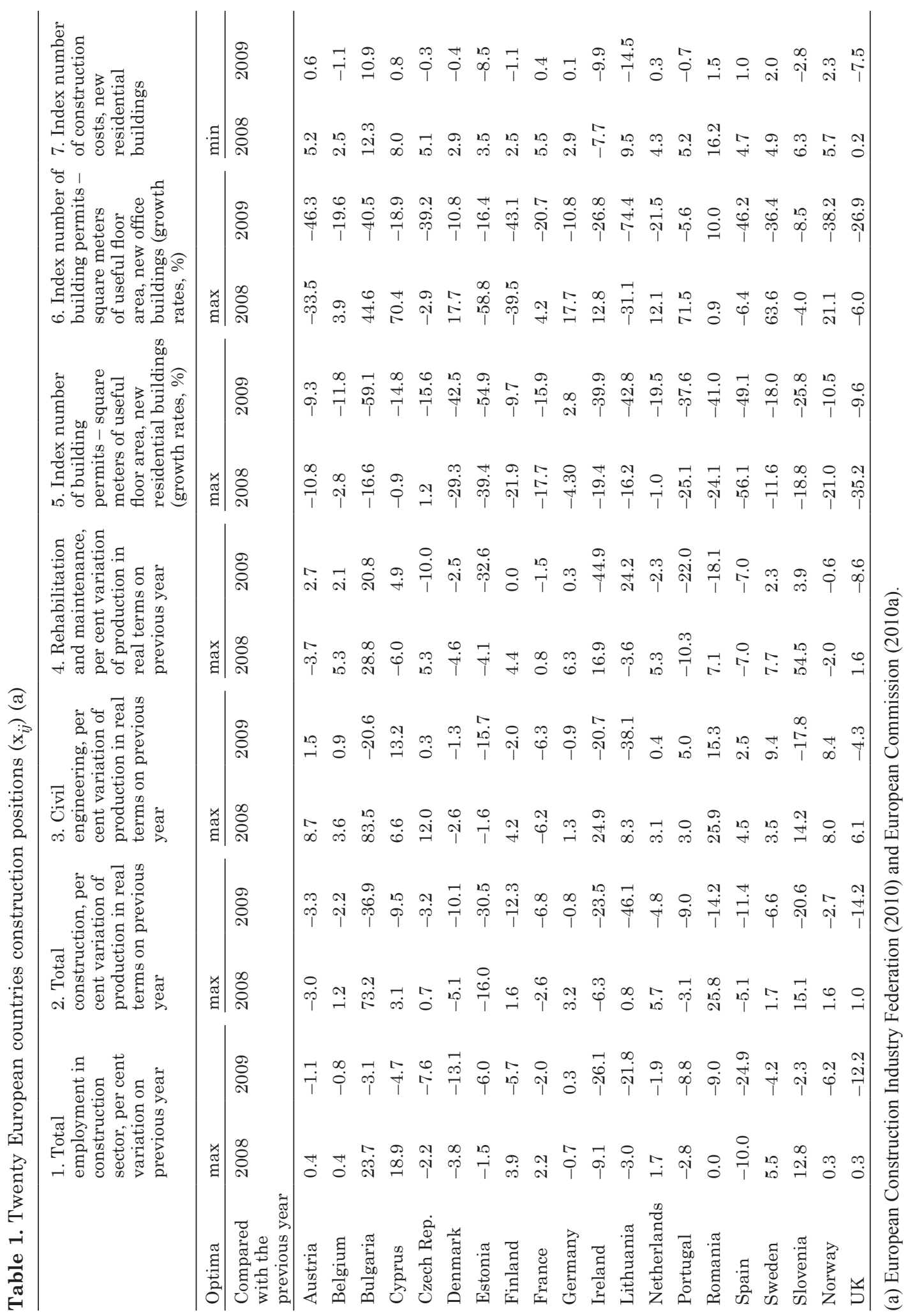




\section{MULTI-OBJECTIVE EVALUATION METHOD MOORA}

Brauers and Zavadskas (2006) proposed the MOORA method. This method has been used by multidisciplinary specialists in various studies, such as in construction and construction management (Kalibatas and Turskis, 2008; Brauers and Zavadskas, 2009), the total economy (Brauers et al., 2007; Balezentis et al., 2010), transport (Brauers et al., 2008b) and manufacturing (Chakraborty, 2011).

MOORA optimization technique with discrete alternatives was used for ranking alternatives in this case study. The Ratio System as a part of MOORA and the Reference Point approach as a part of MOORA mutually control each other (Brauers et al., 2008a). According Chakraborty (2011) MOORA method is simple to comprehend and easy to implement.

The method starts with a matrix of responses of different alternatives on different objectives:

$\left(x_{i j}\right)$

with: $x_{i j}$ as the response of alternative $j$ on objective $i$.

$i=1,2, \ldots, n$ as the objectives.

$j=1,2, \ldots, m$ as the alternatives.

MOORA goes for a ratio system in which each response of an alternative on an objective is compared to a denominator, which is representative for all alternatives concerning that objective. For this denominator the square root of the sum of squares of each alternative per objective is chosen. Brauers and Zavadskas (2006) proved that this is the most robust choice:

$$
x_{i j^{*}}=\frac{x_{i j}}{\sqrt{\sum_{j=1}^{m} x_{i j}^{2}}},
$$

with: $x_{i j}=$ response of alternative $j$ on objective $i$.

$j=1,2, \ldots, m ; m$ - the number of alternatives. $i=1,2, \ldots, n ; n-$ the number of objectives.

$x_{i j}{ }^{*}=$ a dimensionless number representing the normalized response of alternative $j$ on objective $i$.

Dimensionless Numbers, having no specific unit of measurement, are obtained for instance by deduction, multiplication or division. The normalized responses of the alternatives on the objectives belong to the interval $[0 ; 1]$. However, sometimes the interval could be $[-1 ; 1]$. Indeed, for instance in the case of productivity growth some sectors, regions or countries may show a decrease instead of an increase in productivity i.e. a negative dimensionless number.

For optimization these responses are added in case of maximization and subtracted in case of minimization:

$$
y_{j}^{*}=\sum_{i=1}^{i=g} x_{i j}^{*}-\sum_{j=g+1}^{i=n} x_{i j}^{*},
$$

with: $i=1,2, \ldots, g$ as the objectives to be maximized.

$i=g+1, g+2, \ldots, n$ as the objectives to be minimized.

$y_{j^{*}}=$ the normalized assessment of alternative $\mathrm{j}$ with respect to all objectives.

An ordinal ranking in a descending order of the $y_{j}$ shows the final preference if the sum of the maxima is larger than the sum of the minima. In a reversed situation the classification is in an ascending order.

For the second part of MOORA the Reference Point Theory is chosen with the Min-Max Metric of Tchebycheff as given by the following formula (Karlin and Studden, 1966):

$$
\underset{(j)}{\operatorname{Min}}\left\{\max _{(i)}\left|r_{i}-x_{i j^{*}}\right|\right\} \text {, }
$$

with: $\left|r_{i}-x_{i j}{ }^{*}\right|$ the absolute value is important if $x_{i j}{ }^{*}$ is larger than $r_{i}$ for instance by minimization.

This reference point theory starts from the already normalized ratios as defined in the 
MOORA method, namely formula (1). Preference is given to a reference point possessing as co-ordinates the dominating co-ordinates per attribute of the candidate alternatives and which is designated as the Maximal Objective Reference Point. This approach is called realistic and non-subjective as the co-ordinates, which are selected for the reference point, are realized in one of the candidate alternatives. The alternatives A $(10 ; 100), \mathrm{B}(100 ; 20)$ and C $(50 ; 50)$ will result in the maximal objective reference point $R_{m}(100 ; 100)$.

Given the composition of equation (3) the results are ranked in an ascending order.

\section{THE FULL MULTIPLICATIVE FORM AND MULTIMOORA}

In his book of 2004 Brauers (2004a) described the three parts of MULTIMOORA: 1) the Ratio System Approach, producing dimensionless ratios 2) the Reference Point Approach, but still based on scores 3) the Full Multiplicative Form. Some time later he switched over to a Reference Point Approach with instead of scores uses the ratios found in the ratio system (Brauers, 2004b, c). In this way dimensionless measures were obtained again. The synthesis of two approaches was called later MOORA (Brauers and Zavadskas, 2006). In 2010 a third approach was added and MULTIMOORA was born (Brauers and Zavadskas, 2010). Indeed, MULTIMOORA is composed of MOORA and of the Full Multiplicative Form of Multiple Objectives. In this way as up till now no other approach is known satisfying all conditions of robustness and including three or more methods, MULTIMOORA becomes the most robust system of multiple objectives optimization. Brauers and Zavadskas (2010) proposed MOORA to be updated by the Full Multiplicative Form method embodying maximization as well as minimization of purely multiplicative utility function.
The following n-power form for multi-objectives is called from now on a Full-Multiplicative Form:

$$
U_{j}=\prod_{i=1}^{n} x_{i j},
$$

with: $j=1,2, \ldots, m ; m$ - the number of alternatives.

$i=1,2, \ldots, n ; n$ - being the number of objectives.

$x_{i j}=$ response of alternative $j$ on objective $i$.

$U_{j}=$ overall utility of alternative $j$.

The overall utilities $\left(\mathrm{U}_{\mathrm{j}}\right)$, obtained by multiplication of different units of measurement, become dimensionless. The outcome of this presentation is nonlinear, which presents an advantage, as the utility function of human behavior toward several objectives has to be considered as nonlinear.

\section{Objectives moving in a different direction}

How is it possible to combine a minimization problem with the maximization of the other objectives? Therefore, the objectives to be minimized are denominators in the formula:

$$
U_{j}^{\prime}=\frac{A_{j}}{B_{j}},
$$

with: $A_{j}=\prod_{g=1}^{i} x_{g i}$,

$j=1,2, \ldots, m ; m-$ the number of alternatives.

$i=$ the number of objectives to be maximized.

with: $B_{j}=\prod_{k=i+1}^{n} x_{k j}$,

$n-i=$ the number of objectives to be minimized.

with: $U_{j}^{\prime}$ - the utility of alternative $j$ with objectives to be maximized and objectives to be minimized. 
In the Full Multiplicative Form a problem may arise for zero and negative values making the results senseless. Therefore the index number 100 replaces the zero number. At that moment for instance 96.6 substitutes the negative value of minus 3.4. Consequently, 103.4 represents the positive value of 3.4.

The fact that MULTIMOORA assembles all existing methods expressed in dimensionless measures for multi-objective optimization presents a unique feature for this multi-objective optimization.

\section{THE THEORY OF DOMINANCE}

In the most of the not too complicated cases a synthesis of ranking of the three MULTIMOORA methods was made by sight. In this way we mention project management in transition economies (Brauers and Zavadskas, 2010), regional economies (Brauers and Ginevicius, 2010) and isolation studies (Kracka et al. 2010).

For very large matrices Brauers et al. developed a Theory of Dominance (Brauers and Zavadskas, 2011; Brauers et al., 2011).

Axioms on Ordinal and Cardinal Scales

1. A deduction of an Ordinal Scale, a ranking, from cardinal data is always possible (Arrow, 1974).

2. An Ordinal Scale can never produce a series of cardinal numbers (Arrow, 1974).

3. An Ordinal Scale of a certain kind, a ranking, can be translated in an ordinal scale of another kind.

In application of axiom 3 we shall translate the ordinal scale of the three methods of MULTIMOORA in another one based on Dominance, being Dominated, Transitivity and Equability.

\section{Dominance, being Dominated, Transitiveness and Equability Dominance}

Absolute Dominance means that an alternative, solution or project is dominating in rank- ing all other alternatives, solutions or projects which are all being dominated. This absolute dominance shows as rankings for MULTIMOORA: (1-1-1).

General Dominance in two of the three methods with a $\mathrm{P}$ b P c Pd (P preferred to)

is for instance of the form:

$(d-a-a)$ is generally dominating $(c-b-b)$.

$(a-d-a)$ is generally dominating $(b-c-b)$.

$(\mathrm{a}-\mathrm{a}-\mathrm{d})$ is generally dominating $(\mathrm{b}-\mathrm{b}-\mathrm{c})$

and further on transitiveness plays fully.

\section{Transitiveness}

If a dominates $\mathrm{b}$ and $\mathrm{b}$ dominates $\mathrm{c}$ than also a will dominate $c$.

\section{Overall Dominance of one alternative on another}

For instance $(\mathrm{a}-\mathrm{a}-\mathrm{a})$ is overall dominating $(b-b-b)$ which is overall being dominated by $(a-a-a)$.

\section{Equability}

Absolute Equability has the form: for instance (e-e-e) for 2 alternatives.

Partial Equability of 2 on 3 exists e. g. (5-e-7) and (6-e-3).

\section{Circular Reasoning}

Despite all distinctions in classification some contradictions remain possible in a kind of Circular Reasoning.

We can cite the case of:

- Object A (11-20-14) dominates generally object B. (14-16-15).

- Object B. (14-16-15) dominates generally Object C (15-19-12).

- but Object C (15-19-12) dominates generally Object A (11-20-14).

In such a case the same ranking is given to the three objects.

Stakeholders or their representatives may give a different importance to objectives in a multi-objective problem but this is not the case with the three methods of MULTIMOORA. These three methods represent all possible 
methods with dimensionless measures in multi-objective optimization and one can not argue that one method is better than or is of more importance than the others. Consequently no significance coefficients are needed.

\section{EVALUATION BY THE MULTIMOORA METHOD OF THE CONSTRUCTION SECTOR IN TWENTY EUROPEAN COUNTRIES}

First of all the twenty countries were ranked with the help of the Ratio System Method (Appendix $A$, tables $A 1, b$ and $c$ ). The initial decision making matrix (see Table 1 but also A1a) was transformed with the help of the first and second formula and the results were ranked in a descending order if the sum of the maxima was larger than the sum of the minima. In a reversed situation the classification is in an ascending order.

Next method is named Reference Point Method with calculations in accordance with formula 3 (Appendix A, Table A1, c and d). If MOORA is joined with a full multiplicative form for multiple objectives, which is calculated in accordance with formula 4 (Appendix A, Table A2), a total of three methods is joined under the name of MULTIMOORA. These three methods represent all possible methods with dimensionless measures in multi-objective optimization and one can not argue that one method is more important than another.

Table 2 shows the final results for the European States on basis of Dominance Theory (Appendix A, Table A3).

Table 2. Ranking by dominance of the construction sector in 20 European countries by MULTIMOORA (a)

\begin{tabular}{|c|c|c|c|c|c|c|c|c|c|}
\hline $\begin{array}{l}\text { Ranking by } \\
\text { dominance } \\
2008\end{array}$ & Country & $\mathrm{RS}$ & $\mathrm{RP}$ & $\mathrm{MF}$ & $\begin{array}{l}\text { Ranking by } \\
\text { dominance } \\
2009\end{array}$ & Country & $\mathrm{RS}$ & $\mathrm{RP}$ & $\mathrm{MF}$ \\
\hline 1 & Bulgaria & 1 & 1 & 1 & 1 & Germany & 1 & 7 & 1 \\
\hline 2 & Slovenia & 2 & 2 & 3 & 2 & Belgium & 2 & 2 & 2 \\
\hline 3 & Cyprus & 3 & 12 & 2 & 3 & Cyprus & 3 & 11 & 3 \\
\hline 4 & Sweden & 4 & 6 & 4 & 4 & Netherlands & 5 & 8 & 4 \\
\hline 5 & Netherlands & 6 & 4 & 5 & 5 & France & 8 & 9 & 5 \\
\hline 6 & Ireland & 5 & 19 & 6 & 6 & Austria & 4 & 10 & 9 \\
\hline 7 & Germany & 7 & 5 & 7 & 7 & Sweden & 6 & 15 & 7 \\
\hline 8 & Romania & 10 & 3 & 8 & 8 & Norway & 7 & 16 & 6 \\
\hline 9 & Belgium & 8 & 9 & 9 & 9 & UK & 9 & 1 & 10 \\
\hline 10 & Czech Rep. & 9 & 11 & 10 & 10 & Finland & 11 & 3 & 13 \\
\hline 11 & Norway & 11 & 8 & 12 & 11 & Slovenia & 12 & 4 & 11 \\
\hline 12 & Portugal & 12 & 16 & 11 & 12 & Denmark & 13 & 5 & 8 \\
\hline 13 & UK & 13 & 10 & 15 & 13 & Romania & 10 & 13 & 12 \\
\hline 14 & Finland & 14 & 7 & 18 & 14 & Czech Rep. & 14 & 6 & 14 \\
\hline 15 & France & 15 & 15 & 13 & 15 & Portugal & 15 & 12 & 15 \\
\hline 16 & Austria & 16 & 14 & 16 & 16 & Spain & 17 & 14 & 16 \\
\hline 17 & Denmark & 17 & 17 & 14 & 17 & Estonia & 16 & 17 & 17 \\
\hline 18 & Lithuania & 18 & 13 & 17 & 18 & Lithuania & 18 & 18 & 20 \\
\hline 19 & Spain & 19 & 18 & 19 & 19 & Bulgaria & 19 & 20 & 18 \\
\hline 20 & Estonia & 20 & 20 & 20 & 20 & Ireland & 20 & 19 & 19 \\
\hline
\end{tabular}

(a) A bold figure indicates dominance on the following country. (a) European Construction Industry Federation (2010) and European Commission (2010a) 
Table 3. The ranking of the construction sector compared to the national GDP and Strategy Europe 2020 per country

\begin{tabular}{llllll}
\hline $\begin{array}{l}\text { Ranking by } \\
\text { dominance } \\
\text { of } \Delta \text { constr. } \\
\text { sector in } 2008\end{array}$ & Country (a) & $\begin{array}{l}\text { Ranking of } \Delta \\
\text { GDP in } 2008\end{array}$ & $\begin{array}{l}\text { Ranking by } \\
\text { dominance of } \Delta \\
\text { constr. sector in } \\
2009\end{array}$ & $\begin{array}{l}\text { Ranking of } \Delta \text { GDP } \\
\text { in } 2009 \text { (b) }\end{array}$ & $\begin{array}{l}\text { Strategy Europe } \\
2020 \text { realized in } \\
2008\end{array}$ \\
\hline 1 & Bulgaria & $2(6.2 \%)$ & 19 & $13(-4.9 \%)$ & 20 \\
2 & Slovenia & $3(3.7 \%)$ & 11 & $18(-8.1 \%)$ & 5 \\
3 & Cyprus & $4(3.6 \%)$ & 3 & $2(-1.7 \%)$ & 17 \\
4 & Sweden & $17(-0.6)$ & 7 & $14(-5.1 \%)$ & 1 \\
5 & Netherlands & $8(1.9 \%)$ & 4 & $7(-3.9)$ & 8 \\
6 & Ireland & $19(-3.5)$ & 20 & $17(-7.6 \%)$ & 13 \\
7 & Germany & $9(1 \%)$ & 1 & $10(-4.7 \%)$ & 7 \\
8 & Romania & $1(7.3 \%)$ & 13 & $15(-7.1 \%)$ & 19 \\
9 & Belgium & $9(1 \%)$ & 2 & $5(-2.8)$ & 12 \\
10 & Czech Rep. & $6(2.5 \%)$ & 14 & $9(-4.1 \%)$ & 10 \\
11 & Norway & $13(0.7 \%)$ & 8 & $1(-1.4)$ & Nihil (c) \\
12 & Portugal & $14(0.0 \%)$ & 15 & $3(-2.6)$ & 14 \\
13 & UK & $15(-0.1 \%)$ & 9 & $12(-5 \%)$ & 15 \\
14 & Finland & $9(1 \%)$ & 10 & $16(-8 \%)$ & 2 \\
15 & France & $15(-0.1)$ & 5 & $3(-2.6 \%)$ & 7 \\
16 & Austria & $7(2.2 \%)$ & 6 & $7(-3.9)$ & 4 \\
17 & Denmark & $18(-1.1)$ & 12 & $10(-4.7 \%)$ & 3 \\
18 & Lithuania & $5(2.9 \%)$ & 18 & $20(-14.7 \%)$ & 14 \\
19 & Spain & $12(0.9 \%)$ & 16 & $6(-3.7 \%)$ & 11 \\
20 & Estonia & $20(-5.1)$ & 17 & $19(-13.9 \%)$ & 9 \\
\hline
\end{tabular}

(a) EU Countries not included: 1) Luxemburg 2) Latvia 3) Italy 4) Greece 5) Hungary 6) Slovakia 7) Poland 8) Malta (b) Cf. for 2009 the EURO zone: $-4.3 \%$. (c) Norway is not an EU Member State.

It is the intention to come to a comparison between the evolution of the construction sector and of the general economy of each country. As the construction sector was not only characterized by its production but by seven attributes, maximized or minimized to objectives, in the same way the general economics of a country has to be optimized not only by its Gross Domestic Product. Therefore the general rules advanced by "Strategy Europe 2020" were added to GDP.

What is meant by "Strategy Europe 2020"? A Lisbon Strategy was adopted in 2000 and focused on turning the European Union into the most competitive and dynamic knowledge based- economy in the world by 2010 (European Council 2000). However, in 2010 it became clear that many goals of the Lisbon Strategy were not met and therefore a new strategy Europe 2020 was initiated for a "smart, sustainable and inclusive Growth" (European Commission, 2010b).

This new strategy Europe 2020 was summarized into 11 objectives by Balezentis et al. (2011). Unhappily the calculations are only available for 2008 .

These 11 objectives concern:

1. \% Employment rate by gender, age group 20-64. Raising the employment rate for women and men aged 20-64 to $75 \%$.

2. Gross domestic expenditure on R\&D. Raising combined public and private investment levels in research and development to $3 \%$ of GDP.

3. Greenhouse gas emissions (reduction $20 \%)$. 
4. \% Share of renewables in gross inland energy consumption (20\%).

5. \% Energy intensity of the economy (saving 20\% in energy consumption). Objectives 3, 4 and 5 are the so-called "20/20/20" targets.

6. Early leavers from education and training. The share of early school leavers should be under $10 \%$.

7. Tertiary educational attainment by gender, age group 30-34. At least 40\% of the younger generation should have a tertiary degree.

8. Population at risk of poverty or exclusion (ratio).

9. \% People living in households with very low work intensity.

10. At risk of poverty after social transfers. Promotion of social inclusion, in particular by the reduction of poverty, with aim to lift at least 20 million people out of the risk of poverty and exclusion.

11. \% Severe material deprivation.

One has to be aware of the reservations to be made in comparing the seven objectives of the Construction Sector with the single objective of Gross Domestic Product (GDP) and the eleven objectives of Strategy Europe 2020 as is done in Table 3.

Comparing the seven objectives of the Construction Sector with the single objective of Gross Domestic Product (GDP) forms a too narrow comparison whereas the comparison with Europe 2020 forms a too broad comparison. Nevertheless it remains interesting to compare indicators with a different point of view.

\section{COMMENTS ON THE RANKING OF THE CONSTRUCTION SECTOR PER COUNTRY}

On basis of Table 3 following comments can be made.

1) The situation varies significantly from one country to the other. How countries are affected depends on their initial conditions and associated vulnerabilities.

- Countries that entered the crisis with a housing bubble and a large net foreign liability position face a need to shift activity from construction to export-oriented activities and to diminish their dependency on external financing.

- Countries that had been running large current account surpluses and had an associated greater exposure to toxic financial assets need to reduce their export dependency and work off their balance sheet problems.

- The economic policy of a country may vary from one country to another. For instance some countries may follow a policy of increasing public works in order to create an anti-cyclical reaction which often switched over to a pro-cyclical result if the time between decision and execution is too long.

- Bulgaria ranked relatively the highest in construction increase in 2008, but regained its more normal position in 2009. Nevertheless Bulgaria is the less advanced country of the twenty. In 2008 even the GDP went up significantly, but some activities may have swollen the economic activity, whereas the opening of some construction sites could be sufficient to boast the entire construction. Typical is also that the increase in construction is mainly situated in civil engineering, office buildings and in total employment but not at all in residential construction.

- Over the whole period 2008-2009 Germany construction sector (7-1) ranked the best followed by Belgium (9-2) and Cyprus (3-3).

2) The situation varies significantly from one substantial objective to the other.

The construction sector usually reacts to economic changes with some delay, as current activity is based on orders made months/ 
years earlier. It is evident that a situation varies in the construction industry depending on the country's economic development. Every sector of the construction industry, without exception, has been affected by the collapse of the construction bubble and by the challenging economic environment, one more than the others. Governments can incorporate forward-looking structural measures that inject innovation into the mix of policies being adopted to tackle the economic downturn.

3) The construction sector shows cyclical characteristics, which was also the case for the general economy in the period 2007-2009. Nevertheless there was not much correlation between the cyclical movement of the construction sector in each country and of their general economy.

Even worse, comparing the data of tables 1 and 3 it becomes clear that construction in the 20 countries, with exception of Germany, did not stimulate the economy during the recession 2008-2009. German construction, which ranked first of the 20 countries for the whole recession period, showed more or less an anti-cyclical tendency. On the contrary, Belgian construction, ranking second, had a pro-cyclical influence on its declining national economy instead of anti-cyclical one, even despite the fact that the government lowered the Value Added Tax on some construction activities. The downturn in 2009 for Belgian construction came mainly from building permits for residential and office buildings. For the remaining countries construction did not have an outspoken anti-cyclical influence on the respective economies.

4) In 2009 the construction sector in each country was not a forerunner to anticipate on the relative economic upturn of 2010-2011 (growth rates GDP's in EURO zone positive).

A variety of research affirms the lack of cohesion in the market of construction of
European countries. Present situation and perspectives in all countries depends on their development taking into consideration needs, population trends and tastes. Moreover, this market depends on time of occurrence of the particular real estate adjustment and on the economic exposure to financial and economic problems (Kaklauskas et al., 2010, 2011). Economic recession in the construction sector has appeared under the form of delayed investment projects, decreased number of orders, descending production output and the decline in employment (European Construction Industry Federation, 2010).

The relationship between the construction sector and the economy during a crisis has been analyzed by many researchers and economists (Ilhan and Yaman, 2011; You and Zi, 2007; Duca et al., 2010; Goh, 2005; Pellicer et al., 2009; Nadim, 2010). For example, Ilhan and Yaman (2011) have compared the construction sector of European countries with Turkey by applying an „Input-Output” (I-O) model. As Ilhan and Yaman (2011) stated, the 10 sector model shows the intersectoral linkages within the economy. It shows a given country's economic structure over a specific period. The development of European construction sector from a macroeconomic point of view by a correlation analysis has been studied by Pellicer et al. (2009). Nadim (2010) in his article has analyzed the construction industry of the European Union by the offsite production prism (OSP). Duca et al. (2010) review key aspects of the inter-play between financial innovations and housing in generating and propagating the financial and economic crisis facing the Global economy. You and Zi (2007) have utilized the data envelopment analysis method (DEA) and analyzed Korea construction industry effectiveness during the economic crisis. Goh (2005) has described the construction sector development in Singapore during the Asian financial crisis applying intervention analysis. 


\section{CONCLUSION}

Conducting research on basis of statistical indicators for the construction sector during a recession was the topic of this research. After the availability of statistical data 19 EU-Countries of the 27 plus Norway were considered.

Following indicators were used: total construction, total employment in the construction sector, civil engineering, rehabilitation and maintenance, index number of building permits for new residential buildings, index number of building permits for new office buildings and index number of construction costs for new residential buildings.

The evaluation of the construction sector is made by a method called MULTIMOORA. Multi-Objective Optimization by Ratio Analysis (MOORA), composed of two methods, namely Ratio System and Reference Point Theory, the last one starting from the previous found ratios, solves the difficult problem of normalization whereas the importance of the objectives is treated separately. If MOORA is joined with the Full Multiplicative Form for Multiple Objectives, also with the importance of the objectives treated separately, a total of three methods is formed under the name of MULTIMOORA. The MULTIMOORA method can consider all the attributes along with their relative importance, and hence, it can provide a better accurate evaluation of the alternatives. Finally, Dominance Theory is applied to evaluate and to rank the situation of the construction sector in the twenty European countries during the recession 2008-2009.

At the end of 2007 overinvestment in the housing market occurred in the United States followed by a collapse in prices and consequently with losses on the residential mortgages delivered by the American banks. The American banks borrowed from European banks on a too speculative basis. In this way the recession spread to Europe.
During the 2008-2009 recession the construction sector in the 20 European countries did not stimulate the declining different national economies, perhaps with an exception for German construction. Even worse, Belgian construction had a pro-cyclical influence on its national economy despite the fact that the government lowered Value Added Tax on some construction activities.

In addition, the construction sector in each European country was not a forerunner to anticipate on the relative economic upturn of 2010-2011.

\section{REFERENCES}

Arrow, K. J. (1974) General economic equilibrium: Purpose, analytic techniques, collective choice, American Economic Review, 64(3), pp. 253-272.

Auerbach, A. J., Gale, W. G. and Harris, B. H. (2010) Activist fiscal policy, Journal of Economic Perspectives, 24(4), pp. 141-163. http:// dx.doi.org/10.1257/jep.24.4.141

Baležentis, A., Baležentis, T. and Brauers, W. K. M. (2011) Implementation of the Strategy Europe 2020 by the multi-objective evaluation method MULTIMOORA, E+M Economics a Management, 2/2011, several Czech Universities, Praha, pp. 6-21.

Baležentis, A., Baležentis, T. and Valkauskas, R. (2010) Evaluating situation of Lithuania in the European Union: Structural indicators and MULTIMOORA method, Technological and Economic Development of Economy, 16(4), pp. 578602. http://dx.doi.org/10.3846/tede.2010.36

Brauers, W. K. M., Balezentis, A. and Baležentis, T. (2011) MULTIMOORA for the EU member states updated with fuzzy number theory, Technological and Economic Development of Economy, 17(2), pp. 259-290. http://dx.doi.org /10.3846/20294913.2011.580566

Brauers, W. K. M. and Ginevicius, R. (2010) The economy of the Belgian regions tested with MULTIMOORA, Journal of Business Economics and Management, 11(2), pp. 173-209. http:// dx.doi.org/10.3846/jbem.2010.09

Brauers, W. K. M. and Zavadskas, E. K. (2011) MULTIMOORA optimization used to decide 
on a bank loan to buy property, Technological and Economic Development of Economy, 17(1), pp. 174-188. http://dx.doi.org/10.3846/1392861 9.2011 .560632

Brauers, W. K. M. and Zavadskas, E. K. (2010) Project management by MULTIMOORA as an instrument for transition economies, Technological and Economic Development of Econo$m y, 16(1)$, pp. 5-24. http://dx.doi.org/10.3846/ tede.2010.01

Brauers, W. K. and Zavadskas, E. K. (2009) Robustness of the multi-objective MOORA method with a test for the facilities sector, Technological and Economic Development of Economy, 15(2), pp. 352-375. http://dx.doi. org/10.3846/1392-8619.2009.15.352-375

Brauers, W. K. M., Zavadskas, E. K., Peldschus, F. and Turskis, Z. (2008a) Multi-objective decision-making for road design, Transport, 23(3), pp. 183-193. http://dx.doi.org/10.3846/16484142.2008.23.183-193

Brauers, W. K. M., Zavadskas, E. K., Turskis, Z. and Vilutiene, T. (2008b) Multi-objective contractor's ranking by applying the MOORA method, Journal of Business Economics and Management, 9(4), pp. 245-255. http://dx.doi. org/10.3846/1611-1699.2008.9.245-255

Brauers, W. K. M., Ginevičius, R., Zavadskas, E. K. and Antuchevicienè, J. (2007) The European Union in a transition economy, Transformation in Business \& Economics, 6(2), pp. 21-37.

Brauers, W. K. M. and Zavadskas, E. K. (2006) The MOORA method and its application to privatization in a transition economy, Control and Cybernetics, 35(2), pp. 445-469.

Brauers, W. K. (2004a) Optimization methods for a stakeholder society, a revolution in economic thinking by multi-objective optimization, $\mathrm{Se}$ ries: Nonconvex Optimization and its Applications, Volume 73, Kluwer Academic Publishers and Springer, Boston-Dordrecht-London, pp. 342.

Brauers, W. K. (2004b) Multi-objective optimization for facilities management, Journal of Business Economics and Management, 5(4), pp. 173182. http://dx.doi.org/10.1080/16111699.2004.9 636081

Brauers, W. K. (2004c) Multiobjective optimization (MOO) in privatization, Journal of Business Economics and Management, 5(2), pp. 59-66. http://dx.doi.org/10.1080/16111699.2004.9636069
Chakraborty, S. (2011) Applications of the MOORA method for decision making in manufacturing environment, The International Journal of Advanced Manufacturing Technology, 54 (912), pp. 1155-1166. http://dx.doi.org/10.1007/ s00170-010-2972-0

Department of the Environment, Heritage and Local Government (2010) Construction Industry Indicators Prepared for the Department of the Environment, Issue 20 April 2010, Ringsend, Dublin. Available at: <http://www.environ.ie/en/Publications/StatisticsandRegularPublications/ConstructionIndustryStatistics/ FileDownLoad,22919,en.pdf>. [accessed 25 January 2010]

Duca, V. J., Muellbauer, J. and Murphy, A. (2010) Housing markets and the financial crisis of 2007-2009: Lessons for the future, Journal of Financial Stability, 6(4), pp. 203-217. http:// dx.doi.org/10.1016/j.jfs.2010.05.002

European Commission (2010a) Quarterly panorama of European business statistics, ISSN 1725-485X. [Online] Available at: http://epp. eurostat.ec.europa.eu/cache/ITY_OFFPUB/ KS-DL-10-004/EN/KS-DL-10-004-EN.PDF [accessed 29 October 2010]

European Commission (2010b) Communication from the Commission: Europe 2020. A Strategy for smart, sustainable and inclusive growth, 3.3. 2010, COM (2010) 2020.

European Council (2000) Presidency Conclusions, Lisbon, March 23-24, SN 100/00.

European Construction Industry Federation (2010) Advancing construction in Europe. [Online] BCC Guide to Central and Eastern Europe, European Construction Industry Federation (FIEC). Available at: http://www.ciccp.es/ImgWeb/Sede\%20Nacional/folletos/fiec_2010.pdf [accessed 29 October 2010]

Giang, D. T. H. and Pheng, L. S. (2011) Role of construction in economic development: Review of key concepts in the past 40 years, Habitat International, 35(1), pp. 118-125. http://dx.doi. org/10.1016/j.habitatint.2010.06.003

Goh, B. H. (2005) The dynamic effects of the Asian financial crisis on construction demand and tender price levels in Singapore, Building and Environment, 40(2), pp. 267-276. http://dx.doi. org/10.1016/j.buildenv.2004.07.012

Gros, D. and Alcidi, C. (2009) The impact of the financial crisis on the real economy, Intereconomics, 44(4), pp. 1-20. 
Hall, R. E. (2010) Why does the economy fall to pieces after a financial crisis?, Journal of Economic Perspectives, 24(4), pp. 3-20. http://dx.doi. org/10.1257/jep.24.4.3

Ilhan, B. and Yaman, H. (2011) A comparative input-output analysis of the construction sector in Turkey and EU countries, Engineering, Construction and Architectural Management, 18(3), pp. 248-265. http://dx.doi. org/10.1108/09699981111126160

Kaklauskas, A., Kelpšienè, L., Zavadskas, E. K., Bardauskienè, D., Kaklauskas, G., Urbonas, M. and Sorakas, V. (2011) Crisis management in construction and real estate: Conceptual modeling at the micro-, meso- and macro-levels, Land Use Policy, 28(1), pp. 280-293. http:// dx.doi.org/10.1016/j.landusepol.2010.06.008

Kaklauskas, A., Zavadskas, E. K., Bagdonavičius, A., Kelpšienè, L., Bardauskienè, D. and Kutut, V. (2010) Conceptual modelling of construction and real estate crisis with emphasis on comparative qualitative aspects description, Transformations in Business \& Economics, 9(1), pp. $42-61$.

Kalibatas, D. and Turskis, Z. (2008) Multicriteria evaluation of inner climate by using MOORA method, Information Technology and Control, 37(1), pp. 79-83.

Karlin, S. and Studden, W. J. (1966) Tchebycheff systems: With applications in analysis and statistics. Interscience Publishers, New York.

Kracka, M., Brauers, W. K. M. and Zavadskas, E. K. (2010) Ranking heating losses in a building by applying the MULTIMOORA, Inzinerine Ekonomika - Engineering Economics, 21(4), pp. 352-359.

Mishkin, F. S. (2011) Over the cliff: from the subprime to the global financial crisis, Journal of Economic Perspectives, 25(1), pp. 49-70. http:// dx.doi.org/10.1257/jep.25.1.49

National Classification of Economic Activities (2008) Statistical classification of economic activities in the European Community, ISSN 1977-0375. [Online] Available at: http://epp. eurostat.ec.europa.eu/cache/ITY_OFFPUB/ KS-RA-07-015/EN/KS-RA-07-015-EN.PDF [accessed 29 October 2010]

Nadim, W. (2010) Offsite production in the UK: The way forward? A UK construction industry perspective, Construction Innovation, 10(2), pp. 181-202. http://dx.doi. org/10.1108/14714171011037183

Ozkan, F., Ozkan, O. and Gunduz, M. (2011) Causal relationship between construction investment policy and economic growth in Turkey, Technological Forecasting \& Social Change, In Press. http://dx.doi.org/10.1016/j.techfore.2011.04.007

Pellicer, T.M., Pellicer, E. and Eaton, D. (2009) A macroeconomic regression analysis of the European construction industry, Engineering, Construction and Architectural Management, 16(6), pp. 573-597. http://dx.doi. org/10.1108/09699980911002584

Ruddock, L. and Lopes, J. (2006) The construction sector and economic development: The 'Bon curve', Construction Management and Economics, 24(7), pp. 717-723. http://dx.doi. org/10.1080/01446190500435218

You, T. and Zi, H. M. (2007) The economic crisis and efficiency change: Evidence from the Korean construction industry, Applied Economics, 39(13-15), pp. 1833-1842. http://dx.doi. org/10.1080/00036840600690199

Wigren, R. and Wilhelmsson, M. (2007) Construction investments and economic growth in Western Europe, Journal of Policy Modeling, 29, pp. 439-451. http://dx.doi.org/10.1016/j.jpolmod.2006.10.001

Wilhelmsson, M. and Wigren, R. (2011) The robustness of the causal and economic relationship between construction flows and economic growth: Evidence from Western Europe, $A p$ plied Economics, 43(7), pp. 891-900. http:// dx.doi.org/10.1080/00036840802600020 


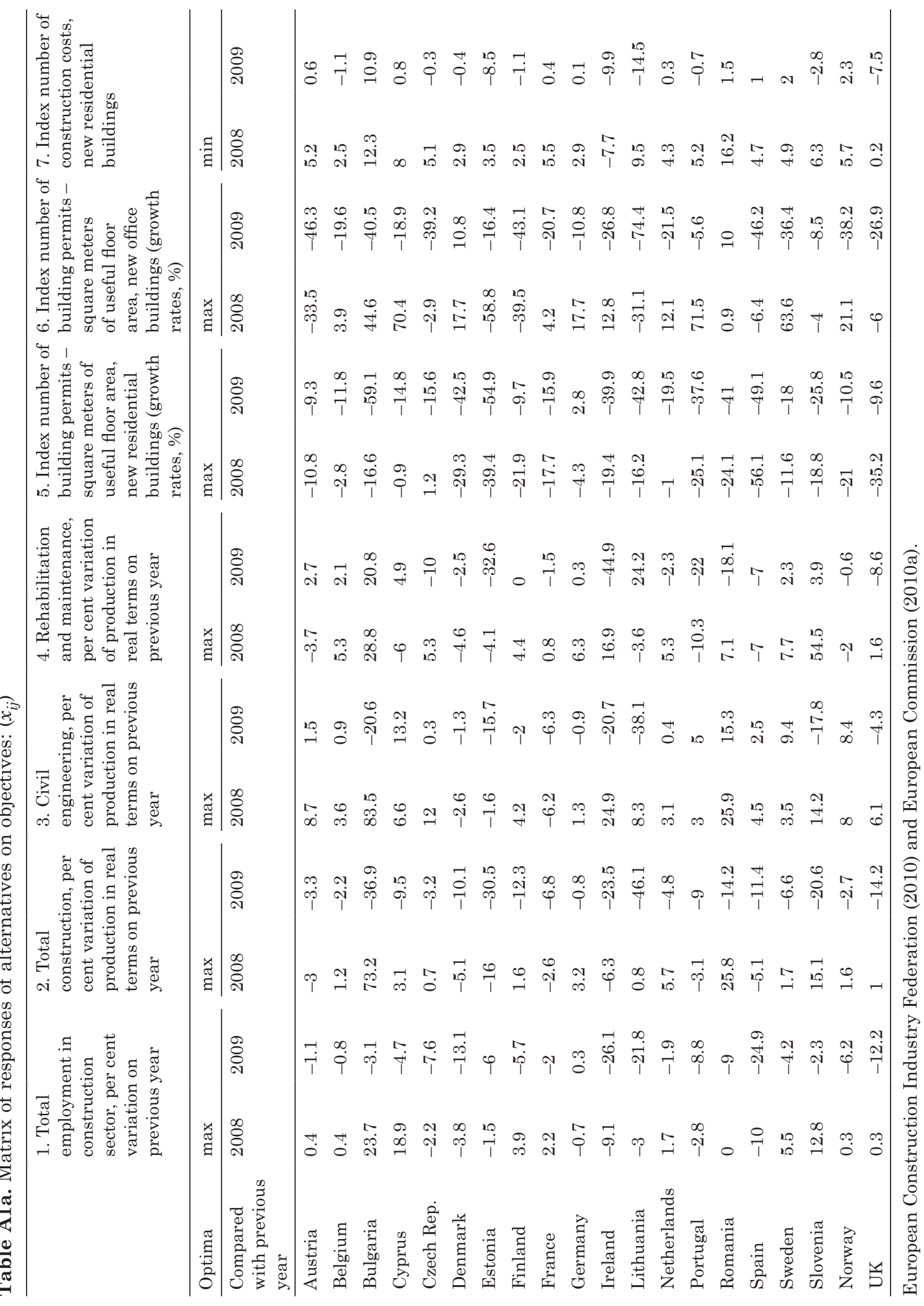




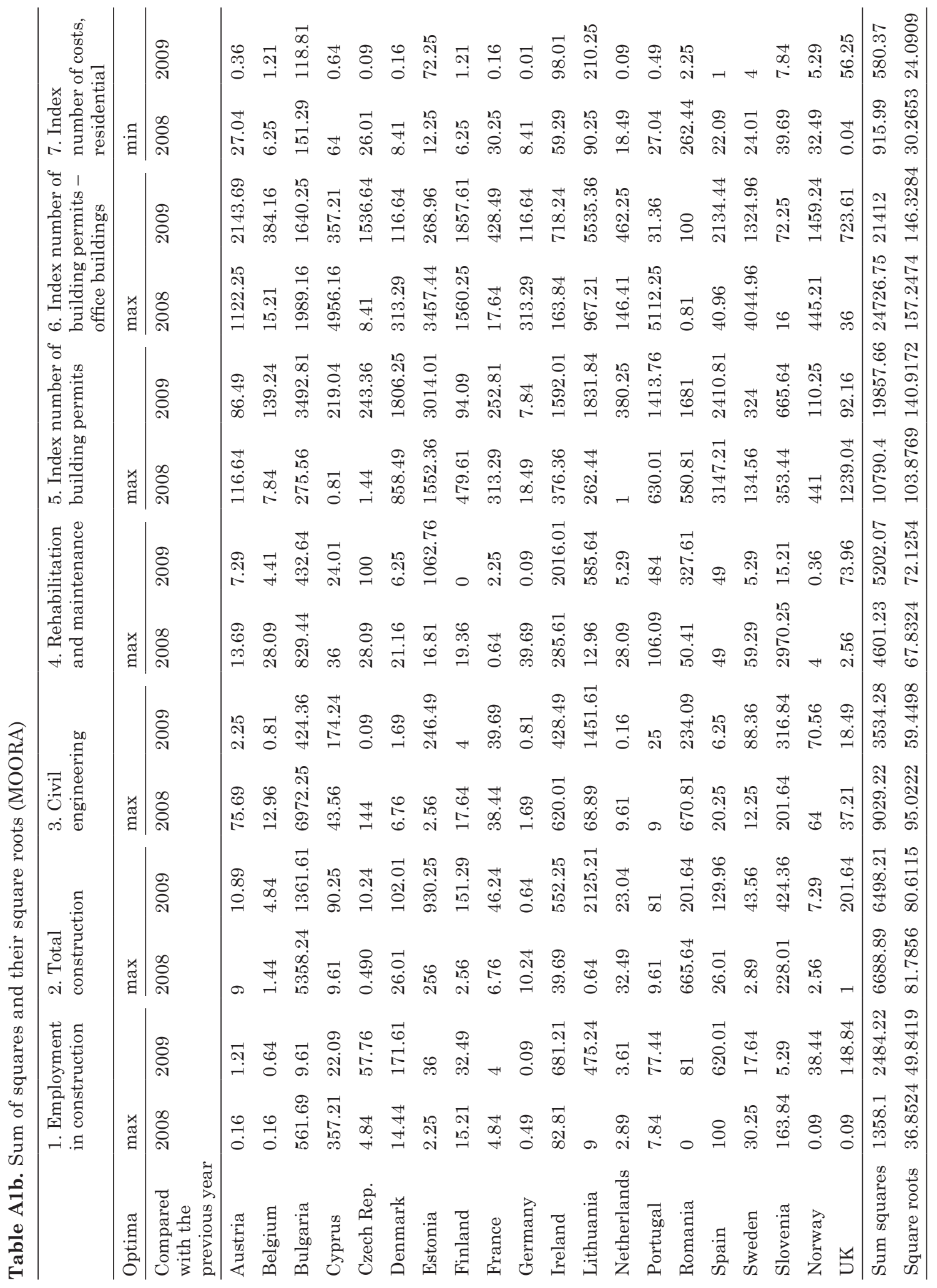




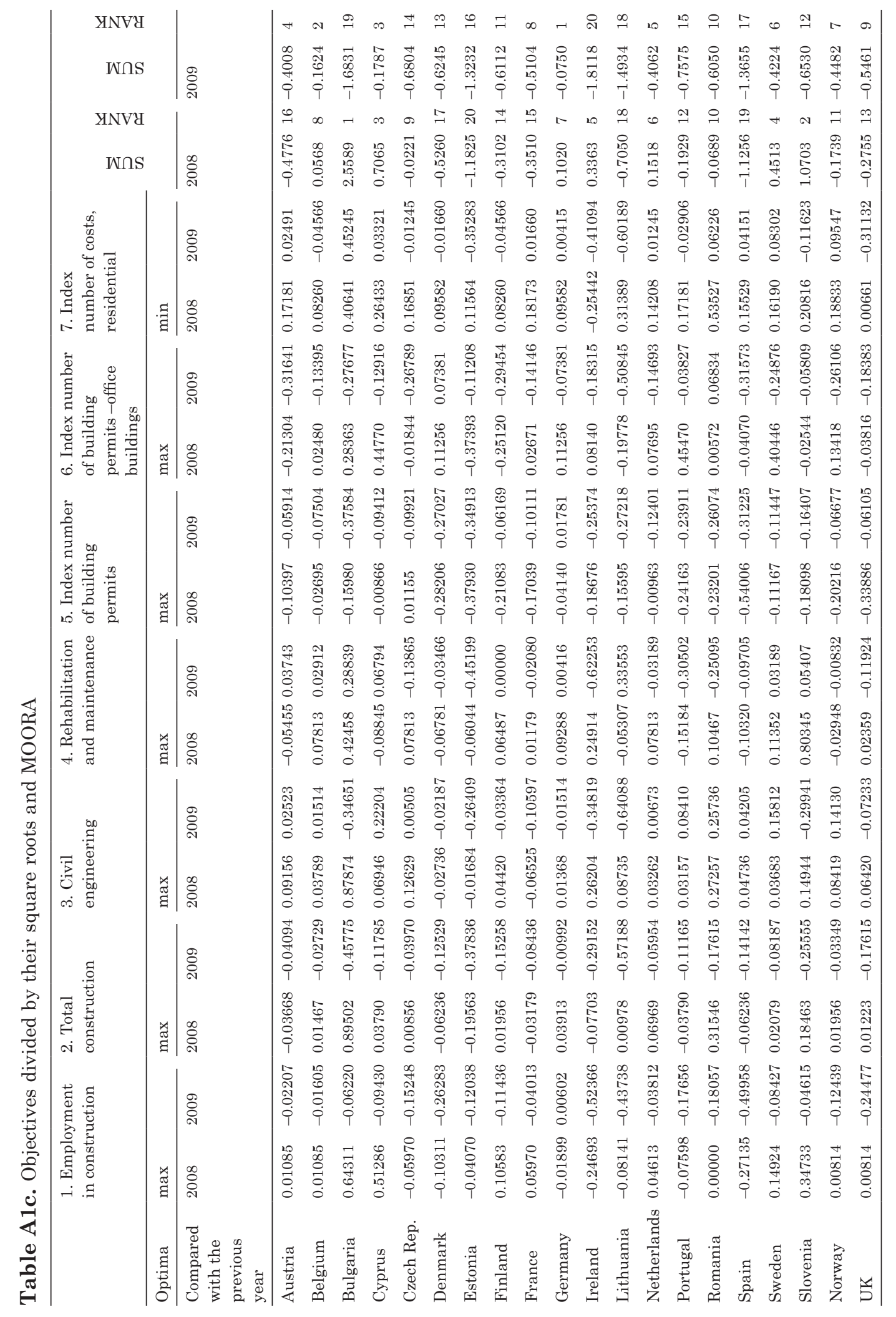




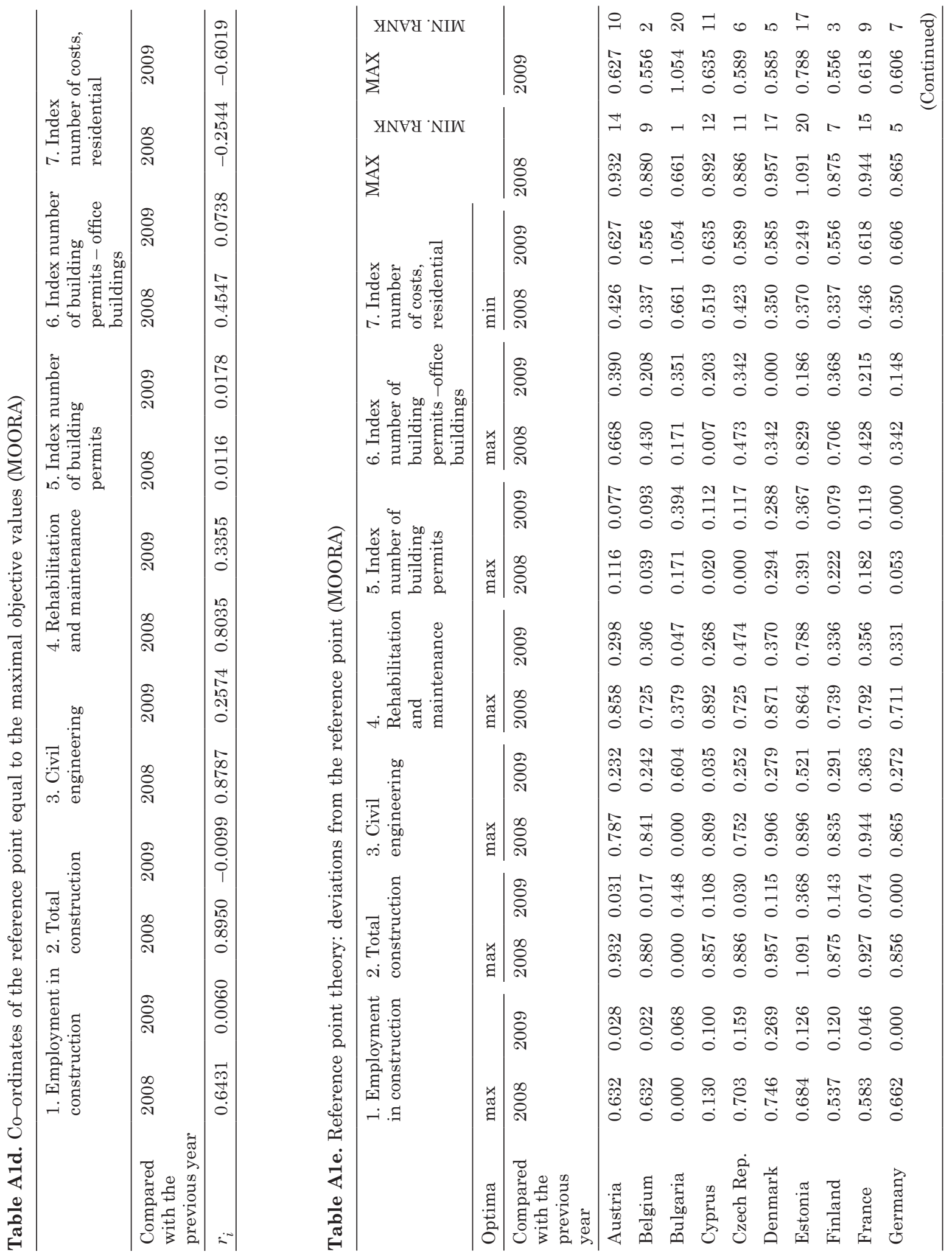




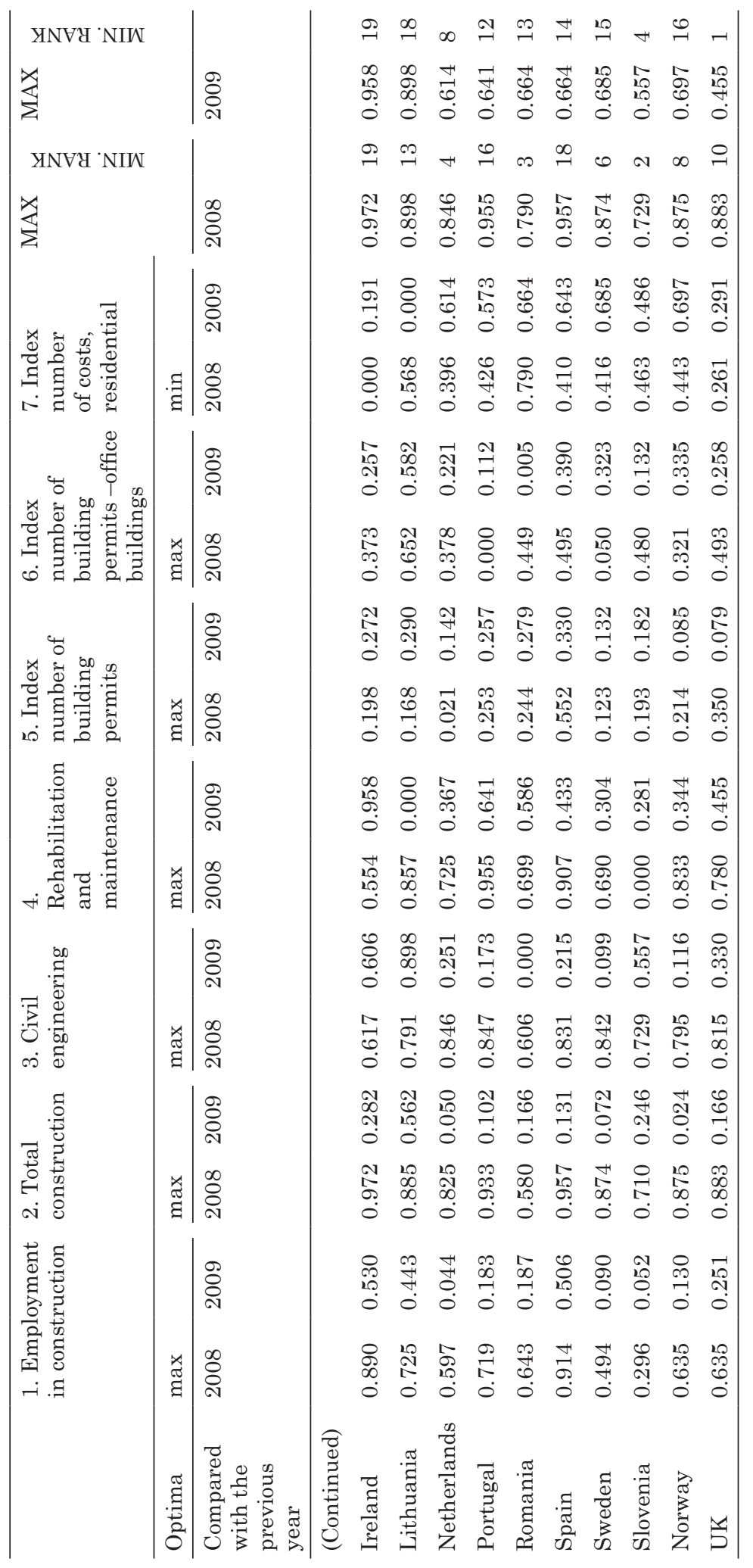


Table A2a. The full multiplicative form and ranks of states, 2008

\begin{tabular}{lllll}
\hline Countries & \multicolumn{2}{l}{2008} & $\mathrm{U}=\mathrm{A} / \mathrm{B}$ & \multirow{2}{*}{ RANK } \\
\cline { 2 - 5 } & $\mathrm{A}$ & $\mathrm{B}$ & 5748202221 & 16 \\
\hline Austria & $6.047 \mathrm{E}+11$ & 105.2 & 10920946989 & 9 \\
Belgium & $1.119 \mathrm{E}+12$ & 112.3 & 54378109669 & 1 \\
Bulgaria & $6.107 \mathrm{E}+12$ & 108 & 19206360119 & 2 \\
Cyprus & $2.074 \mathrm{E}+12$ & 105.1 & 10859547908 & 10 \\
Czech Rep. & $1.141 \mathrm{E}+12$ & 102.9 & 6860079014 & 14 \\
Denmark & $7.059 \mathrm{E}+11$ & 103.5 & 1883470024 & 20 \\
Estonia & $1.949 \mathrm{E}+11$ & 102.5 & 5293708418 & 18 \\
Finland & $5.426 \mathrm{E}+11$ & 105.5 & 7650473545 & 13 \\
France & $8.071 \mathrm{E}+11$ & 102.9 & 12079381050 & 7 \\
Germany & $1.243 \mathrm{E}+12$ & 92.3 & 12249626983 & 6 \\
Ireland & $1.131 \mathrm{E}+12$ & 109.5 & 5382535195 & 17 \\
Lithuania & $5.894 \mathrm{E}+11$ & 104.3 & 12417651735 & 5 \\
Netherlands & $1.295 \mathrm{E}+12$ & 105.2 & 10625513123 & 11 \\
Portugal & $1.118 \mathrm{E}+12$ & 116.2 & 11179507101 & 8 \\
Romania & $1.299 \mathrm{E}+12$ & 104.7 & 3257629193 & 19 \\
Spain & $3.411 \mathrm{E}+11$ & 104.9 & 16488818661 & 4 \\
Sweden & $1.730 \mathrm{E}+12$ & 106.3 & 16798596894 & 3 \\
Slovenia & $1.786 \mathrm{E}+12$ & 105.7 & 9762043067 & 12 \\
Norway & $1.032 \mathrm{E}+12$ & 100.2 & 6638447677 & 15 \\
UK & $6.652 \mathrm{E}+11$ & &
\end{tabular}

Table A2b. The full multiplicative form and ranks of states, 2009

\begin{tabular}{lllll}
\hline Countries & 2009 & & & \multirow{2}{*}{ RANK } \\
\cline { 2 - 4 } & $\mathrm{A}$ & $\mathrm{B}$ & $\mathrm{U}=\mathrm{A} / \mathrm{B}$ & \\
\hline Austria & $4.856 \mathrm{E}+11$ & 105.2 & 6615567264 & 9 \\
Belgium & $7.087 \mathrm{E}+11$ & 102.5 & 1270869890 & 18 \\
Bulgaria & $1.427 \mathrm{E}+11$ & 112.3 & 6552395274 & 3 \\
Cyprus & $7.077 \mathrm{E}+11$ & 108 & 3942158492 & 14 \\
Czech Rep. & $4.143 \mathrm{E}+11$ & 105.1 & 4654718985 & 8 \\
Denmark & $4.790 \mathrm{E}+11$ & 102.9 & 1352205191 & 17 \\
Estonia & $1.400 \mathrm{E}+11$ & 103.5 & 4062688391 & 13 \\
Finland & $4.164 \mathrm{E}+11$ & 102.5 & 5328862728 & 5 \\
France & $5.622 \mathrm{E}+11$ & 105.5 & 8813122098 & 1 \\
Germany & $9.069 \mathrm{E}+11$ & 102.9 & 1177374192 & 19 \\
Ireland & $1.087 \mathrm{E}+11$ & 92.3 & 433340857 & 20 \\
Lithuania & $4.745 \mathrm{E}+10$ & 109.5 & 5550287260 & 4 \\
Netherlands & $5.789 \mathrm{E}+11$ & 104.3 & 3805931580 & 15 \\
Portugal & $4.004 \mathrm{E}+11$ & 105.2 & 4117944205 & 12 \\
Romania & $4.785 \mathrm{E}+11$ & 116.2 & 1658952110 & 16 \\
Spain & $1.737 \mathrm{E}+11$ & 104.7 & 4978526474 & 7 \\
Sweden & $5.222 \mathrm{E}+11$ & 104.9 & 4231498255 & 11 \\
Slovenia & $4.498 \mathrm{E}+11$ & 106.3 & 5145977326 & 6 \\
Norway & $5.439 \mathrm{E}+11$ & 105.7 & 4345682800 & 10 \\
UK & $4.354 \mathrm{E}+11$ & 100.2 &
\end{tabular}


Table A3. The MULTIMOORA method and final ranks of European states

\begin{tabular}{|c|c|c|c|c|c|c|c|c|}
\hline \multirow[t]{2}{*}{ Countries } & \multicolumn{2}{|c|}{$\begin{array}{l}\text { Rank of full } \\
\text { multiplicative form }\end{array}$} & \multicolumn{2}{|c|}{ Ratio system } & \multicolumn{2}{|c|}{ Reference point } & \multicolumn{2}{|c|}{$\begin{array}{l}\text { Ranking based on } \\
\text { dominance }\end{array}$} \\
\hline & 2008 & 2009 & 2008 & 2009 & 2008 & 2009 & 2008 & 2009 \\
\hline Austria & 16 & 11 & 16 & 9 & 18 & 16 & 16 & 12 \\
\hline Belgium & 9 & 2 & 9 & 3 & 7 & 14 & 9 & 4 \\
\hline Bulgaria & 1 & 20 & 1 & 17 & 1 & 19 & 1 & 19 \\
\hline Cyprus & 3 & 3 & 3 & 5 & 5 & 3 & 3 & 3 \\
\hline Czech Rep. & 10 & 13 & 10 & 13 & 14 & 11 & 10 & 13 \\
\hline Denmark & 14 & 14 & 14 & 16 & 8 & 8 & 14 & 15 \\
\hline Estonia & 20 & 16 & 19 & 6 & 20 & 12 & 20 & 14 \\
\hline Finland & 17 & 8 & 17 & 10 & 19 & 5 & 17 & 7 \\
\hline France & 12 & 9 & 13 & 1 & 16 & 1 & 13 & 1 \\
\hline Germany & 6 & 1 & 7 & 20 & 10 & 15 & 7 & 16 \\
\hline Ireland & 4 & 18 & 5 & 19 & 4 & 18 & 4 & 18 \\
\hline Lithuania & 18 & 19 & 18 & 8 & 17 & 20 & 18 & 20 \\
\hline Netherlands & 7 & 5 & 8 & 15 & 9 & 4 & 8 & 5 \\
\hline Portugal & 8 & 15 & 6 & 2 & 6 & 9 & 6 & 9 \\
\hline Romania & 13 & 6 & 12 & 18 & 12 & 7 & 12 & 8 \\
\hline Spain & 19 & 17 & 20 & 18 & 13 & 17 & 19 & 17 \\
\hline Sweden & 2 & 7 & 2 & 7 & 3 & 10 & 2 & 6 \\
\hline Slovenia & 5 & 4 & 4 & 4 & 15 & 2 & 5 & 2 \\
\hline Norway & 11 & 12 & 11 & 11 & 2 & 13 & 11 & 11 \\
\hline UK & 15 & 10 & 15 & 12 & 11 & 6 & 15 & 10 \\
\hline
\end{tabular}

